\title{
Changes and challenges following the 1997 Colfiorito earthquake: the evolution of the use of the Internet for large seismic events
}

\author{
Giuliana Rubbia and Romano Camassi \\ Istituto Nazionale di Geofisica e Vulcanologia, Milano, Italy
}

\begin{abstract}
The September 26, 1997 Central Italy earthquake represents the first Italian large seismic event on the occasion of which Internet was intensively exploited to exchange and disseminate data, information and news. The paper illustrates how national and international seismological institutions disseminate information about earthquakes ten years ago. A web evolution is sketched, and some features that can be of interest today in the seismological community are presented.
\end{abstract}

Key words Internet - World Wide Web - Colfiorito earthquake

\section{Introduction}

The occurrence of a strong earthquake represents an opportunity for the scientific community to acquire new information, to better understand the geological and seismotectonic context, and to verify hypotheses and provide those new. For the general public who live through the direct experience of an earthquake and for those who experience it indirectly through the mass media, a seismic crisis obviously has a very different significance.

In emergency situations, the research institutes involved have great responsibilities both towards the public bodies and towards the population. One of these responsibilities is to provide tools to allow the understanding of the phe-

Mailing address: Dr.ssa Giuliana Rubbia, Istituto Nazionale di Geofisica e Vulcanologia, via Bassini, 15 20133 Milano, Italy; e mail: rubbia@mi.ingv.it nomenon underway, to realistically predict its possible evolution, and to provide information that allows the best organisation of the emergency response, in all its forms.

The Umbria-Marche seismic sequence of 1997/98 represented a unique experience from a number of points of view, and in particular from the point of view of communication. The occurrence of a strong earthquake in an area apparently at the edges of more active seismic zones, and the complexity and long duration of the sequence, all put great strain on the ability to understand the event (which many have since defined incorrectly as an «anomaly»), and above all, its «communication».

Specifically in those years, the Internet was becoming an important tool for communication, and therefore the representations of this event through the websites of the research bodies and organs of information provide an interesting element for reflection. For the first time in Italy, and maybe in the World, an earthquake was heavily reported through the Internet, as well as through newspapers and television.

While the television coverage of the collapse of the roof of the Basilica of Assisi reported this 
to the World as «the Assisi earthquake», a webpage of a group of Italian researchers that was active in real time became, for the first time, a tool for communication and for the sharing of information, data and their interpretation without limitation, thus becoming an experience for which the originality and value probably remain to be fully appreciated.

\section{1997: the beginning}

In 1997, the telematic infrastructure of Italy was mature enough to allow for routine use of electronic mail and the Internet for the exchange and dissemination of data, information and news. For the first time after the 1980 Irpinia earthquake, on the occasion of the Umbria-Marche seismic sequence, seismological research centres found themselves experimenting with this new medium to communicate not only within the scientific community, but also

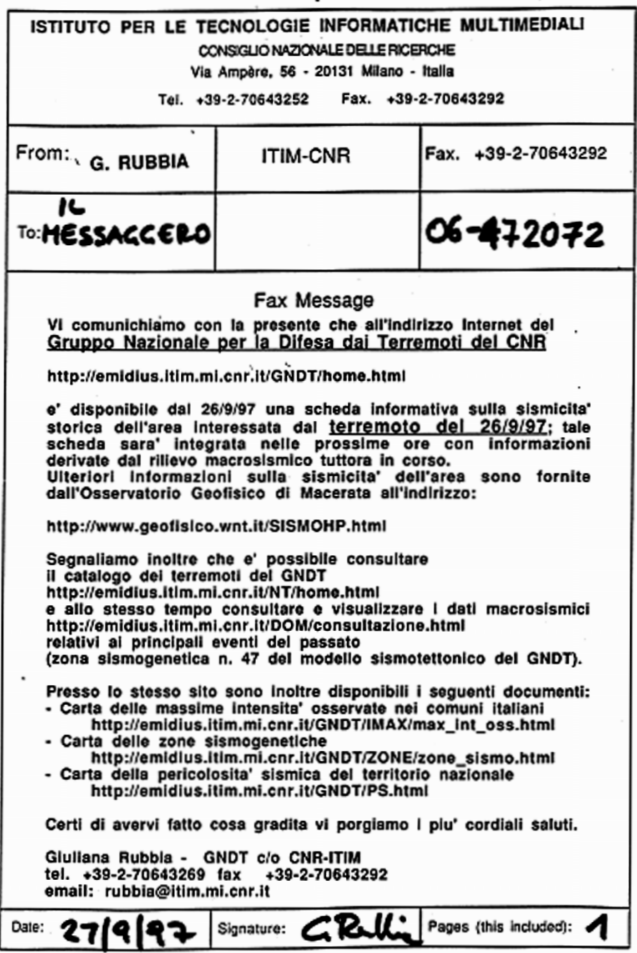

outside of it, to the news agencies and to the general public.

On the morning of Saturday, September 27, 1997, the day after the main shocks, nearly thirty editorial offices of Italian newspapers received a fax informing them that some preliminary information about the seismicity of the affected area was already available from the website maintained by the National Group for the Protection against Earthquakes (Gruppo Nazionale per la Difesa dai Terremoti; GNDT). Enzo Vitale, a journalist with the high circulation daily newspaper Il Messaggero, embedded this press release in its entirety in an article published on Sunday, September 28 (figs. 1, 2).

The GNDT website that was dedicated to the Umbria-Marche seismic sequence of September/ October 1997 was hurriedly set up on September 26. The aim of the initiative was to supply the scientific community and other users with the available in-progress information in the shortest possible time. The website started

Fig. 1. Fax Message sent on September 27, 1997 by the webmaster of Gruppo Nazionale per la Difesa dai Terremoti to the daily newspaper Il Messaggero. «We announce that on the website of Gruppo Nazionale per la Difesa dai Terremoti of National Research Council http://emidius.itim.mi.cnr.it/ GNDT/home.html, a report is available about the historical seismicity of the area stroke by the earthquake of 26/9/97; the report will be updated in the next hours with information provided by the macroseismic survey which is still carried on. Further information are provided by Osservatorio Geofisico di Macerata at http://www.geofisico.wnt.it/SISMOHP .html

We notify that it is also possible to browse the GNDT earthquake catalogue http://emidius.itim.mi. $\mathrm{cnr} . \mathrm{it} / \mathrm{NT} / \mathrm{home} . \mathrm{html}$ and at the same time to retrieve and visualize macroseismic data of most significant past event http://emidius.itim.mi.cnr.it/DOM/consultazione.html (seismogenic zone no.47 according to seismotectonical model by GNDT). On the same website the following documents are available:

Map of Maximum Observed Intensities in the Italian Municipalities, http://emidius.itim.mi.cnr.it/GNDT /IMAX/max_int_oss.html; Map of seismogenic zones http://emidius.itim.mi.cnr.it/GNDT/ZONE/ zone_sismo.html, Map of seismic hazard of the Italian territory http://emidius.itim.mi.cnr.it/PS.html. Best regards». 


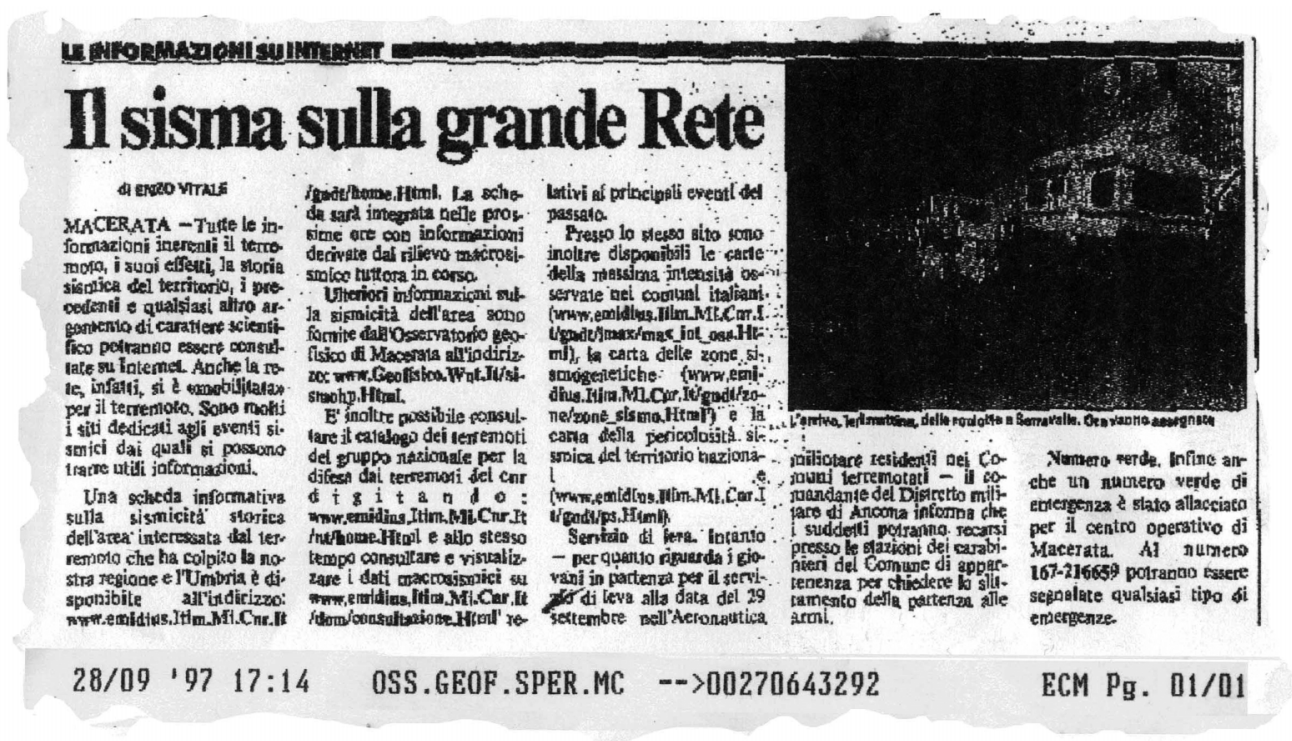

Fig. 2. Article by Enzo Vitale published on Il Messaggero on Sunday, 28, 1997 sent by Osservatorio Geofisico di Macerata to the GNDT web staff. Note how it refers largely to GNDT fax message of fig.1.

with a web page that presented the historical seismicity of the affected area and links to the website of the National Institute of Geophysics (Istituto Nazionale di Geofisica; ING), which was charged with the seismic monitoring activity (Amato, 2007). This website was progressively enriched and updated with information and preliminary results of the activities and investigations being carried out by a number of researchers and technicians of the GNDT, universities, and other institutions. It was even translated into English to serve the international audience, and it is still available, although no longer maintained, at http://emidius.mi.ingv.it/ GNDT/T19970926/ (URL1 fig. 3).

This website carried out the functions of requesting, gathering and processing in real time scientific and information contributions for the Internet, relative to the seismic sequence underway; it also had the function of publicising the materials provided by other web servers. Moreover, it also made available the seismicity data that were focused on the area of interest, using again the seismic databanks that had already been made available on-line as the deliverables from projects for Civil Protection, as described by (Padula and Rubbia Rinaldi, 1999).

Some of the contributions included:

- Macroseismic surveys (Camassi, 2007) carried out by the ING, the GNDT and the National Seismic Service (Servizio Sismico Nazionale, SSN), which were updated to 20 October, 2007;

- Macroseismic data in terms of the European Macroseismic (EM-92) scale;

- Correlations between damage and site amplification;

- Navigation through virtual earthquake scenarios;

- Evidence for surface faulting;

- Observations of the geological effects along the Quaternary faults;

- The earthquakes of September/October 1997 in the framework of the tectonics and long-term seismicity of the Umbria-Marche (central Italy) Apennines;

- The main historical earthquakes of the Umbria-Marche region;

- The earthquakes in the Umbria-Marche region from the NT4.1 catalogue; 
- Maximum observed intensities in the communities of Umbria-Marche from 1000 to 1980 ;

- The seismic histories of the main localities;

- Expedite damage scenarios;

- The seismic hazard of the region.

On this occasion, significant use of this system of communication was seen for the first time: the pattern of access to the webserver, parallelling the seismic sequence, revealed the interest and the search for information (Rubbia, 1998, Danna, 1998). This pattern was later to be revealed as typical, with increases in the accessing of the sites of the public bodies on the occasions of seismic events (Rubbia 2004), with peaks that also reached to two orders of magnitude, as, for example, on the occasion of the San Giuliano di Puglia earthquake in 2002.

We are still able to access the information that was published through those days, if not totally, at least partially, due to the thorough policies of preservation and maintenance, as well as to the global Internet archiving projects like the Wayback Machine (URL2).

Searching among the pages stored by the Wayback Internet Machine, we can retrieve the ING and SSN sites, which provided special pages. The ING provided lists of the aftershocks and macroseismic effects, maps of the historical and recent seismicity, information about the mobile network and the macroseismic questionnaire, and a link page (URL3).

From the stored ING page of the links, we can retrieve special web pages of other regional observatories, like the Macerata Experimental Geophysics Observatory (Osservatorio Geofisico Sperimentale di Macerata; OGSM), a local research unit of the GNDT (URL4), the PreAlpine Geophysics Centre (Centro Geofisico Prealpino; URL5) and other interesting evidence, like the webpage maintained by the Order of Friar Minor, for the San Francesco Basilica in Assisi that was seriously damaged by the main shock (URL6).

If we search among the organs of information and the media, we can find, for example, the special RAI television pages (http://www.mediamente.rai.it) that promised to provide a «panorama of the resources available now on the Internet, from which information and advice can be obtained through the various phases of the earthquake emergency» (URL7). However, using the same system, it is not possible to recover the news and the special sections, for example, of the national daily newspapers, such as La Repubblica, available through Wayback Machine from 1998, and Il Corriere della Sera. In this way, the maintenance of an electronic press review by a research body, such as by, for example, the press office of Istituto Nazionale di Geofisica e Vulcanologia - INGV, has value for the future.

It is important to stress that the European organisations that today have specific roles in the collection and dissemination of information in real time for earthquakes in Europe and throughout the World (in particular the European-Mediterranean Seismological Centre [EMSC-CSEM]) activated their websites or special earthquake pages only later.

The EMSC, which was founded in 1975 and was charged by the Council of Europe $(\mathrm{CoE})$ in 1987 to provide them with seismic warnings in the framework of an Open Partial Agreement (OPA) on the prevention of, protection against, and organisation of relief for major natural and technological disasters, opened their institutional website in early 1998 (Le Dren, 1998).

Similarly, ORFEUS, the Observatories and Research Facilities for European Seismology, which is a European non-profit organisation, aimed at coordinating and promoting digital, broad-band seismology in Europe, provided waveform data since the middle of the 1990's through several on-line and off-line request methods.

Furthermore, special web pages featuring «Recent earthquakes in the news» can be retrieved for significant earthquakes since 1999. For example, there is the Izmit earthquake of August 17, 1999, in Turkey, with the stored pages available at URL8; this includes ORFEUS/EMSC moment tensor solutions, «local information» (as pointers to local observatories), and links to other resources, like the «Special event pages» prepared by IRIS - Incorporated Research Institutions for Seismology URL9). 
One of the most interesting examples that is of major impact for the general public proposed by the website of GNDT in 1997, was the webpage providing the possibility of a virtual exploration of the epicentre area (in QuickTime Virtual Reality; QTVR, a file format which allows the assembling of digital photos into panoramas, that can be explored in three dimensions, changing the point of view). This webpage allowed interactive navigation through the damage scenarios of seven localities in the Umbria-Marche Apennines (fig. 4).

The use of the QTVR technique was proposed for the first time in the representation of earthquake damage, and this experimentation remains one of the most important experiences of this type that has even been realised. The public interest in this experiment is documented by the large numbers of reports in the press and on websites worldwide (USA Today, 1997, Eudes and Lubrano, 1997). The original webpage, initially run from the CINECA web server, remained on-line uninterrupted from 1998 to 2004 (URL10), and it can still be accessed through URL11. This technique represents the earthquake effects in a very realistic way, and allows an «immersion» and interactive exploration of complex situations that can never be adequately represented by static images or video recordings where the user is simply a passive spectator.

A further application, proposed on the occasion of the Izmit earthquake in 1999 (Mucciarelli et al., 2002), also demonstrates very well the aspects of this sort of documentation that are of scientific interest, which allow a later deeper evaluation of certain aspects of particular scientific interest (the typology and distribution of damage in a potentially unlimited context). The experimentation of this technique has been very limited outside of the Italian context. Some QTVR videos were made during the Seattle earthquake of February 28, 2001 (Bohonus, 2001), and more recently a couple of QTVR videos were made by the United States Geological Service (USGS) during the Sumatra earthquake of 2004 (USGS, 2005).

Eight years later, in 2004, the reporting on a global scale of two great emergencies - the Katrina hurricane and the Tsunami in south-east
Asia - represented a final development, transforming them into two massive media events, due mainly to the generalised diffusion of digital photographs and videos, both through the Internet and through satellite television channels. However, from the point of view of the dissemination of scientific data from and for the scientific community and for the general public, the revolution arrived earlier, towards the end of the 1990's, through the Internet.

The information centre that is definitely one of the most important in the field of seismology in the World is the National Earthquake Information Center (NEIC) of the USGS. It is therefore very interesting to examine how the main World earthquakes are represented on the website of the USGS. Neither the list of large earthquakes in 1997 of the NEIC (URL12), nor the historical worldwide earthquakes webpage of the USGS provide detailed information about the Umbria-Marche earthquake in 1997 (URL13). On the latter, the systematic reports on the most important worldwide earthquakes starts from 1998.

Overall, over the course of these last ten years, the webpages dedicated to descriptions of the strong earthquakes have maintained very similar structures, while providing information that is always more enriched. These webpages represent the direct expression of a large research institute and they are aimed essentially at the world of research.

\section{The evolution}

The «Electronic Seismologist» columns and some papers in the journal Seismological Research Letters published around 1997 can give us a feel of how Internet use has increased and how its potential has been perceived and progressively exploited within the seismological community.

At the beginning, in the mid-1990's, data and resources started to be available over the World Wide Web and to be listed by their Internet addresses. Malone (1995a,b) illustrated some Internet protocols and initiated the core of his Seismosurfing list, the starting point for many information seekers. This provided Inter- 
net-type connections where original seismic data or seismic research information was available. Malone (1996) reviewed some of the seismic sources that were made available on the Internet in near-real time, within minutes to hours of the event's occurrence, while Wald (1997) provided a survey of Internet listings of strong motion data, and Van Eck (1997) provided a comprehensive list of seismological and related software that was organized by topics and had URL links for its sources.

One of the first reports available on the USGS webpage relates to the magnitude 7.5 earthquake that occurred south-east of Taiwan on May 3, 1998 (URL14); the webpage provides the parameters of the event, some descriptive remarks, and links to related sites on historical seismicity, moment tensor solutions, and seismic hazard maps, among others. Since 2002, among the related webpages, there has been a link to the webpage «Did you feel it?», although the descriptive information remains substantially the same. For the Sumatra earthquake in 2004, the webpage becomes a lot more complex, and it is organised in five sections, as: Details, Summary, Maps, Scientific and Technical, and Additional Information (URL15).

The increase in connectivity led seismological centres to collect data and information from the population equipped with an Internet access on occasion of earthquakes.

Cajka and Halchuk (1998) reported their experiments for the collection of data from the general public on the occasion of two small earthquakes in Canada, with an analysis of the advantages and disadvantages with respect to the use of the postal paper-based questionnaire. Although they pointed out that «Internet users are not necessarily representative of the general population, as one suspects they are more highly educated and certainly more technology oriented», they felt that the number of Internetconnected urban and rural Canadian households would only increase, and that, moreover, hosting the questionnaire on their website also gave the general population an opportunity to share its experiences, thus helping to relieve post-trauma stress. The first fully automated system to provide an on-line source for rapidly collected and processed earthquake data was re- ported on by Wald et al. (1999), for the rapid «Community Intensity Maps» provided through the USGS, as now available at URL16.

In the introduction to Jones et al. (2000), Malone pointed out three basic features of Internet information dissemination on the occasion of seismic events: the availability of online searches by journalists soon after the event, «Reporters now race to their computers and point their web browsers at the nearest seismic network where they can count on finding, within minutes, an automatic but 'official' location»; the difficulties in providing reliable information to non-specialist users, «Determining the location and size of the event rapidly is one thing, but communicating that to the public in a reliable, consistent and clear way is another»; and the efficiency of the web servers that is required by the high number of access requests, «Unfortunately, if there are many users for such pages, many may get nothing because of an overload of web servers».

In this context, Jones et al. (2000) described the design of a standard way to make information available over the Internet on the occurrence of an earthquake, as was carried out by the USGS on the basis of their recent experiences at the time. Here, there were three principles that guided the design: «1) keep page and maps simple so that they can be updated quickly; 2) keep pages and maps small (in bytes) to reduce the load of the server after felt events; and 3) keep HTML usage simple and standard to accommodate the variety of browsers used by folks to access the pages.». They even discussed the problem of establishing web-safe colours, and, moreover, took into account potential visual impairments of the user: «We also quickly discovered that earthquakes coloured by age using red and green were indistinguishable to a colour-blind seismologist, leaving only a fewer colours with which to work».

The distribution of information «for everybody» thus began to be discussed, with usability and accessibility issues included in the design and development phases. This usability referred to «The extent to which a product can be used by specified users to achieve specified goals with effectiveness, efficiency and satisfaction in a specified context of use», according 
to the ISO 9241-11 definition (1998); in this case, this referred to, for example, pages that could be rapidly opened by the users and that could be rapidly modified by the operators. In this way, the data can be regularly updated, and therefore with efficacy as well as efficiency. The information accessibility also referred to the ability to provide information that is available to people with disabilities, through the use of the correct strategies and technical implementation, such as, in this case, care in the choice of colours for the colour-blind seismologist, taking into account one of the Web Content Accessibility Guidelines (see for example URL17).

Indeed, it is worth noting that the USGS web site implemented an accessibility policy (Section 508) in 2001. This Section 508

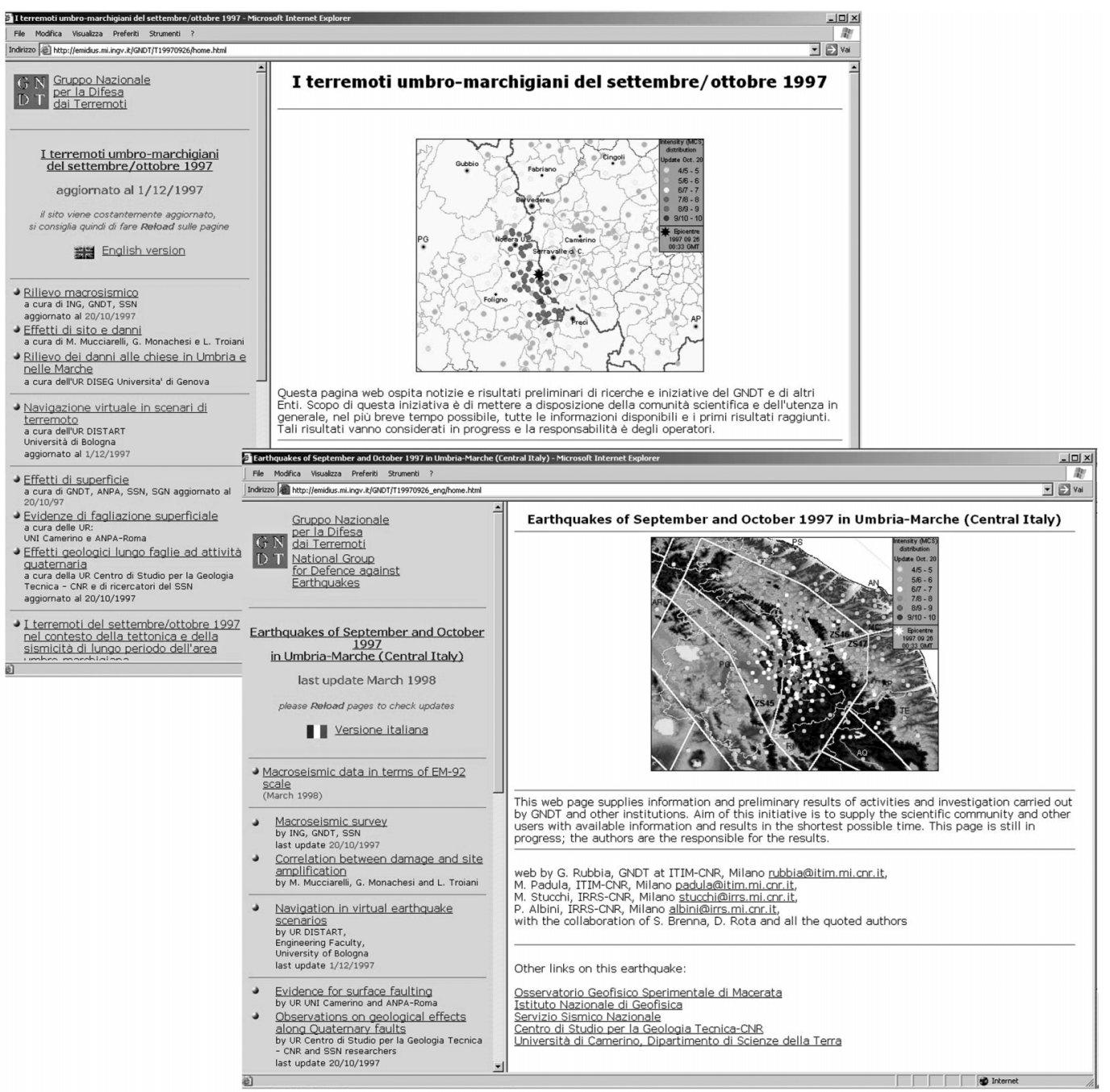

Fig. 3. Homepages of the Italian and English version of the GNDT web site dedicated to the Umbria-Marche seismic sequence. 
(URL18) requires that all electronic and information technology of Federal agencies is accessible to people with disabilities. In Italy, similar quality principles were formalised in the Law \#4, of 9 January, 2004: Provisions to support the access to information technologies for the disabled, which was also known as «The Stanca Act» (URL19).

\section{2007: the challenges of today}

The evolution of information and communication technologies has led to a significant increase in the ability to acquire data, and process and disseminate information, through dedicated websites and web applications. This increase has clearly been perceived by institutions supplying information, which have started to pay more attention to the analysis of web server statistics. For example, Archuleta et al. (2006) illustrated the increase in usage of the COSMOS web portal of strong-motion data over the years, and plan to collect more information relating to the profiles of visitors who download the seismic records; similar considerations can be found in (Rubbia, 2000, 2004) and (Borriello et al., 2006).

As a consequence of the pervasiveness of web technology and the increase in the number of connections, this Internet use itself represents a source of information: two European data centres have thus used this Internet traffic information as complementary to seismic alerts. The EMSC has experimented with «felt maps», that is maps which represent the area where an event has been felt from the variations of geographic origin of the website visitors; as surges in website traffic can occurr within 2-5 minutes, this tool can be considered very fast to collect in-situ information on the effect of an earthquake (Bossu et al. 2007). Similarly, but on a different basis, the 'NINTRAS' service of the Swiss Seismological Service (ETH-SED) provides an alert system complementary to RedPuma, which is derived from the access rate to the SED website and from the frequency of earthquake-related words in news agencies and on media webpages (Kradolfer and Heimers, 2003).
On the occasion of significant earthquakes, what kind of data do seismologists want over the web? What is the information that a more general audience seek? What are the key factors that need to be considered in this communication process? Are there templates and procedures ready to be used during the next earthquake? Can people contribute?

Van Eck et al. (2007) provided an inventory of programmes and web applications that have been taken into account in the design of the portal that is one of the objectives of the ongoing Network of Research Infrastructures for European Seismology (NERIES) European Community project (2006-2009). The tentative classification provided can be helpful in the design of the concept and architecture of a portal that is aimed at facilitating the use and distribution of earthquake seismological data for research, seismic monitoring, hazard mitigation and public relations. Furthermore, a careful analysis of user profiles is given, including «General Public, Educational, Observatory, Scientist, Decision maker», and of the variety of requirements with respect to raw, derived and interpreted data, such as, for example, waveform data, parameters, shakemaps, etc.

There have been many web-based applications developed at the INGV and that are today available for the dissemination of data and information on seismic events and for interactions with the users in the territory. These include for example: seismic events localised by the Italian National Seismic Network through Google Maps (Doumaz and Vinci 2006, Mazza et al. 2006); maps of the effects of earthquakes, produced through the elaboration of the data collected by the macroseismic questionnaire on-line (De Rubeis et al., 2007). The Italian National Earthquake Center (Centro Nazionale Terremoti, CNT of INGV) provides for each earthquake detected by Italian National Seismic Network and by the Mediterranean Network Mednet a special page which data and maps plotted from databanks run by INGV. This kind of page includes parameters of the event, revised localization of the earthquake, and for the epicentral area: hazard maps, shakemaps, moment tensors, macroseismic map derived from on line questionnaires, and waveform data in 
SAC format. Both the list of recent earthquakes and the Did you feel it? page are available from the INGV home page at http://www.ingv.it (URL20). The new version of the INGV home page, which today has contributions from personnel who in 1997 were part of ING and GNDT, is realised through one of the most popular open-source, content-management systems, Plone, and aims to progressively satisfy the requirements for accessibility of Law \#4/2004.

This technological evolution is coupled to the further diversification of the roles of the Internet users themselves, and it forms part of the transition from Web 1.0 to the so-called 'Web 2.0'. Although the definition of Web 2.0 remains controversial, according to an article in Wikipedia it refers to a set of web services that facilitate creativity, collaboration and sharing between users, such as blogs, wikis, podcasts, RSS - Really Simple Syndication feeds (URL21).
Through its CoreCast service, USGS provides access to monthly episodes and segments covering up-to-date information, stories, and events on subjects such as natural hazards and other topics (URL22). Podcasts can be downloaded directly as mp3 files, into iTunes or via a subscription.

A RSS service allows to be alerted when content of interests appear on favorite websites. «Instead of visiting a web site to browse for new articles and features, RSS automatically notifies you when something new is posted online all through your downloaded news reader» (URL23). RSS is routinely used to notify news releases and data about earthquakes by USGS, EMSC (URL24), INGV (URL25).

YouTube, considered the largest videosharing site on the Internet, is today very popular for the diffusion of audio and visual materials. For example, the well known sequences of the collapse of the roof of the Basilica in Assisi is now available a posteriori on

\section{www. nettuno. it/eventi/terremoto}

\section{Deux sismologues proposent une visite de villages italiens touchés par les tremblements de terre}

LE SÉISME du 26 septembre dernier qui a frappé les provinces italiennes d'Ombrie et des Marches n'a pas seulement endommagé des monuments historiques. Plusieurs villages des Apennins, moins médiatiques, ont gravement souffert. Or, ce sont eux qui intéressent en priorité les scientifiques, car ils sont situés tout près de l'épicentre. Pour permettre à leurs collègues étrangers et aux internautes du monde entier de mieux comprendre ce qui s'est passé, MM. Camassi et Monachesi, deux sismologues de l'université de Bologne, ont mis en place un site web inédit et spectaculaire, faisant appel à la technique du Quick Time Virtual Reality (OTVR): ils proposent une visite dynamique de quatre localités sinistrées, Annifo, Arvelo, Saint-Martino et Cesi, reconstituées grâce à un enchainement de photos à 360 degrés dans lesquelles l'internaute se déplace librement.

Le site consacré à Annifo est le plus abouti. La tournée d'inspection commence sur la place du village: grâce à sa souris, le visiteur virtuel peut «tourner sur lui-même » à son

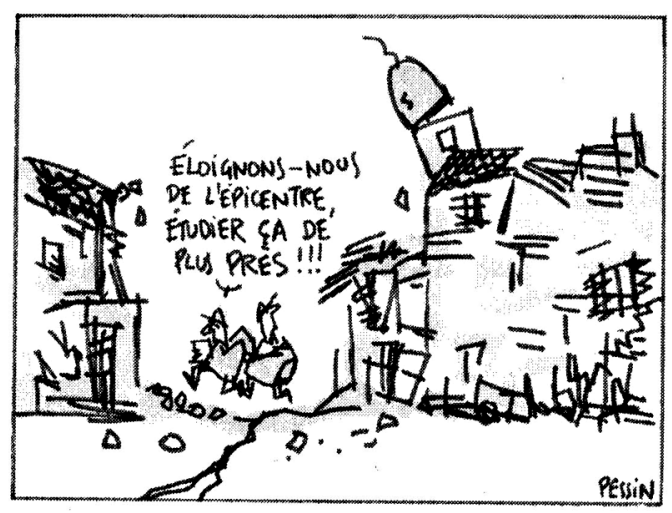

gré ou encore regarder vers les toits lézardés ou le sol encombré de gravats. Pour évaluer plus précisément les dégâts, il peut zoomer sur un détail. Lorsqu'il est face à une rue en enfilade, un passage, ou une porte, il lui suffit de cliquer pour avancer et se retrouver dans le lieu visé - une cour, un jardin, une autre place également reproduit à 360 degrés. « Pour décrire une scène de tremblement de terre, les mots ne suffisent pas. Des photos classiques ou une séquence vidéo auraient été plus explicatifs qu'un texte, mais tout aussi subjectifs, car ils traduisent les choix du photo- graphe ou du cameraman. En revanche, des prises de vue circulaires intégrales sont relativement objectives ", explique M. Monachesi. II ajoute que les reconstitutions en QTVR sont un outil exceptionnel pour étudier la relation entre l'étendue des dégâts et le type de construction. Tous ces fichiers peuvent également être téléchargés.

Depuis le 26 septembre, plusieurs autres séismes ont touché la région. Annifo, Arvelo, Saint-Martino et Cesj sont désormais complètement détruits. Les sismologues ne sont pas retournés sur les lieux prendre de nouvelles photos, mais pour l'avenir il projettent de créer des «excursions virtuelles " de plusieurs zones à des stades différents, ce qui permettra d'étudier plus précisément l'évolution des destructions. En attendant, leur site web est le dernier témoin des dommages provoqués par la première secousse et l'ultime souvenir en images des quatre villages encore debout.

Yves Eudes et Sébastien Lubrano

Fig. 4. Paper by Yves Eudes et Sébastian Lubrano appeared on Le Monde, October 22, 1997, dealing with the «virtual» exploration of the epicentral zone. 
(URL26). However, this is actually not of any particular significance today as it is an old contribution that is little representative of 'that' earthquake. Nevertheless, it can be predicted that on the occasion of the next strong earthquake, YouTube will be a very rich site for the diffusion of digital documentation, a situation that will have an unpredictable impact on communication, from the emotional and institutional points of view.

If we search for the term «terremoto» («earthquake» in Italian, but also in Spanish) in Youtube, we found nearly 6,000 videos, most of them indexed by the same word in Spanish. Among the first results, a huge amount is dedicated to the Peru August, 2007 event. We can retrieve just some videos of most important earthquakes in Italy of the past 30 years including Friuli, 1976, Irpinia 1980 (URL27), Umbria-Marche, 1997. They are «in memory of», and refer to television news. The sonorous recording of the first one shake of the Friuli's earthquake (North Italy), for example, posted on October 2006, collected over 18,000 views and 40 comments in more than one year. After months of silence, comments came back on January 2008 on the occasion of another earthquake: these comments are by (probably young) people from Southern Italy that have experienced the close Southern Greece event on 5 January, 2008 (URL28). It is worth noting that all these videos were posted from the second half of 2006; most clicks come from referring pages that belong to blogs that are mantained by individual young people or groups. The most recent post is on the occasion of the 40th anniversary of the Belice (Sicily), 1968 earthquake (URL29); it refers to several cerimonies and exhibitions related to the event; the authors belong to a local community. As for mid January 2008 , results for the term «earthquake» include more than 8,500 files $(11,000$ the day after); results sorted by view counts show videos of the Peru 15/8/2007 Earthquake: videos were posted the same day of the earthquake, or in the following days; hundreds of comments and responses of people experiencing the earthquake are available.

Direct evidence and digital contributions are always more frequently being requested by the sites of the research institutes. The EMSCCSEM, for example, has prepared a relevant questionnaire and asks for photographs and videos illustrating the effects of earthquakes experienced to be sent. Thus you can report your experience through a web form (URL30), where it is asked: Have you taken a picture/video about the effects of an earthquake? Please, share it with us (URL31) (Mazet-Roux et al., 2008).

It is difficult today to imagine if and how these tools will be used and what they will produce in the future. The replies to these requests can be very different from country to country, and are very dependent on the familiarity that the public has with the Internet and the digital tools, and on their willingness to interact with the sites of the public bodies and research centres, etc. Nevertheless, some experiences in EMSC tend to demonstrate that as soon as the web site offer some information/service perceived as valuable by the visitor, he/she is keen to share his/her experience and data.

As stated during the 2832nd Competitiveness (Internal market, Industry and Research) Council of Europe meeting in Brussels at the end of November 2007, «the Internet has created unprecedented possibilities to disseminate, share and build on the outcome of research efforts; Information and Communication Technologies revolutionise the way scientists communicate, perform research and produce knowledge (URL32)».

At the same time, the technology is only one of the factors that enable information processes. We fully agree with the quality principles that, for example, have arisen from the Ministerial Network for Valorising Activities in Digitisation (Minerva) European project to promote good practice towards the complete availability of information content (Minerva WG5, 2003).

A cultural public website must be «transparent» regarding its own objectives and those of the group that manages it, provide content in an «effective» way for its users, be well «maintained» and up to date, be «accessible» to all independently from the technology used and of disabilities, be «user friendly», be «interactive» through mechanisms for responses to questions and discussions, be «multilingual», be «inter- 
operable», that is connected with the cultural networks, be «managed» according to the norms regarding intellectual property rights and privacy and with the appropriate details of the terms of use of its content and services, be «preserved», i.e. continued over the long term, for example, thanks to archiving strategies and adoption of web standards that can ensure longterm availability of contents (URL33).

\section{Conclusions}

The experience of the website for the Colfiorito earthquake of 1997/98 took form exactly at the moment when the Internet began, in Italy, to be a tool for the dissemination of technical and scientific information for public bodies and research centres. This website, in particular, had the merit of diffusing, elaborating and interpretating data in (nearly) real time for an event of great scientific, and also social, relevance, for the world of research and, more in general, for the public of the Internet. These data (scientific, in its strictest terms) allowed further elaboration, and also elaboration by others not «in the field» (Gasperini et al., 1999). The complexity and the long duration of the sequence were critical elements for public communication, and in the first weeks the GNDT website was an essential reference point for following the process and an element of absolute transparency: a scientific laboratory open to all on the one side, and an essential source for the media and the general public on the other.

As the 1997 Colfiorito earthquake was the first one that occurred in Italy at the beginning of the Internet era, it triggered some reflections about how earthquake information was spread at that time, what changes have happened in the past decade, what factors should be taken into account on the occasion of next significant one, or in preparing its communication.

The reconstruction of the 1997 state of the art and of available contents was realized mainly through web pages stored in the Internet Archive. This archive allowed to retrieve the frozen versions at certain time of web pages that are no longer available; its use pointed out the need of preservation policies on the one hand and the value of projects of preserving digital contents on the other.

The «historical» perspective of online seismic related contents enabled by the Internet Archive together with an analysis of some dedicated literature revealed that a) during years, progressively greater attention has been paid to users either as information consumers or information providers; b) a mix of earthquake related information has reached a «stable» configuration.

Increased attention to users refers to web development techniques that allow to reach a broader audience in a more efficient and effective way: developments according to web standards - W3C technologies enabling future-proof documents - as well as to usability and accessibility principles will be rewarding; it also means to acquire information about the territory from Internet connected people that felt the earthquake (e.g. from the «Did you feel it?» questionnaires and invited photos and videos, ...).

On the other hand, easy to use and low cost web publishing tools has led to the growth of the so-called User Generated Contents. Contributions to blogs, explanations took from Wikipedia and videos made by people that experienced the earthquake began to appear in the last two years, although not yet fully experimented in Italy.

In this scenario, several categories of information suppliers are present: seismological information centers, research institutions, public bodies, media, social networks, ... At the website of a research centre, the general public expects scientifically founded information, an overview of an event in its context, and interpretations thereof. For these reasons, perhaps, the 1997 Umbria-Marche website was ahead of the times, by ten years? But, what's next?

Professional organizations, such as seismological research centers and monitoring institutions will play a key role and need to evaluate improvement about how to provide reliable, understandable and rapid information.

To improve, we suggest to take into account reccomendations and guidelines that emerge from above mentioned current wide-ranging initiatives and international projects, in the frame- 
work of accessibility for all, quality of digital contents, and large seismological infrastructures.

\section{Acknowledgements}

The authors wish to thank Rémy Bossu of European-Mediterranean Seismological Center, the other anonymous reviewer and the editors for their critical reading and suggestions for improving the manuscript.

\section{APPENDIX - UNIFORM RESOURCE LOCATORS OF WEB PAGES QUOTED IN THE TEXT}

URL1 I terremoti umbro-marchigiani del settembre/ottobre 1997 http://emidius.mi.ingv.it/GNDT/T19970926/

URL2 Internet Archive Wayback Machine http://www.archive.org/index.php

URL3 Istituto Nazionale di Geofisica Homepage (as retrieved from the Internet Archive) http://web.archive.org/web/19971023010410/ http://www.ingrm.it/index.html

URL4 Osservatorio Geofisico di Macerata http://web.archive.org/web/19980123235740/ www.geofisico.wnt.it/SISMOHP.html

URL5 Centro Geofisico Prealpino Sismi Umbria-Marche http://www.astrogeo.va.it/sismi/umbria.htm

URL6 Earthquake in Italy by Order of Friar Minor http://web.archive.org/web/19971021074058/ http://www.ofm.org/quake/quakeeng.htm

URL7 Il terremoto in Umbria e nelle Marche http://web.archive.org/web/19971008065634/ http://www.mediamente.rai.it/speciali/terremot/ terremot.htm

URL8 ORFEUS - Observatories and Research Facilities for European Seismology http://web.archive.org/web/20010426185324/ orfeus.knmi.nl/earthquake-news-1999.html

URL9 IRIS: Special Event Page August 17, 1999 - Turkey Quake http://web.archive.org/web/20010411170748/ www.iris.washington.edu/DOCS/turkey.htm

URL10 Terremoti umbro-marchigiani del 26 settembre 1997- Navigazione virtuale nei centri abitati della zona epicentrale http://web.archive.org/web/1999 0219135739/ www.nettuno.it/eventi/terremoto/

URL11 Earthquakes of September and October 1997 in Umbria-Marche (Central Italy) http://emidius.mi.ingv.it/GNDT/T19970926_ eng/home.html

URL12 National Earthquake Information Center - NEIC:1997 Large events http://web.archive.org/web/ 19990117060901/wwwneic.cr.usgs.gov/neis/ bulletin/97_EVENTS/97_EVENTS.html

URL13 Historic Worldwide Earthquakes http://earthquake.usgs.gov/regional/world/historical.php
URL14 USGS - Preliminary Earthquake Report Magnitude 7.5 Southeast of Taiwan 1998 May 03 http://neic.usgs.gov/neis/eq_depot/1998/eq_ 980503/

URL15 USGS - 2004 Earthquake and News Headlines Archive http://earthquake.usgs.gov/eqcenter/eqinthenews/2004/

URL16 USGS Did You Feel It? Community Internet Intensity Maps http://earthquake.usgs.gov/eqcenter/dyfi.php

URL17 Web Content Accessibility Guidelines 1.0. W3C Recommendation 5-May-1999 http://www.w3.org/TR/WAI-WEBCONTENT/

URL18 Section 508: The Road to Accessibility http://www.section508.gov

URL19 Law n. 4, January 9, 2004. Published text translated in English by the Information Systems Accessibility Office at CNIPA (National Organism for ICT in the Public Administration of Italy) http://www.pubbliaccesso.it/normative/law_2004 0109_n4.htm

URL20 Istituto Nazionale di Geofisica e Vulcanologia Homepage http://www.ingv.it

URL21 Article on Web2.0 from Wikipedia, the free encyclopedia. http://en.wikipedia.org/wiki/Web_2.0

URL22 USGS CoreCast http://www.usgs.gov/corecast/

URL23 USGS Podcasts and RSS Feeds http://www.usgs.gov/rss/

URL24 EMSC RSS Feeds http://www.emsc-csem.org/ index.php?page $=$ current $\&$ sub $=$ rss

URL25 INGV RSS Feeds http://www.ingv.it/rss-2

URL26 YouTube Earthquake Assisi, Italy - Terremoto Assisi, Italia 1997 http://www.youtube.com/watch?v=u1Fer3yMo5I

URL27 YouTube Terremoto dell'Irpinia (23 nov. 1980) http://youtube.com/watch?v=jyRPiIl9V8I

URL28 YouTube Terremoto Friuli 1976 - Earthquake Friuli (Italy) 1976 http://youtube.com/watch?v=UODyP9qCY_g

URL29 YouTube 2008 Santa Margherita Belice - Banda Croce Rossa Italiana http://youtube.com/watch?v=A6Wvdr2QgvQ

URL30 EMSC Report your experience http://www.emsc-csem.org/index.php?page $=$ rye $\&$ sub $=$ choose

URL31 Have you taken a picture/video about the effects of an earthquake?

http://www.emsc-csem.org/index.php?page=rye $\&$ sub $=$ pics

URL32 Council of European Union. Council Conclusions on scientific information in the digital age: access, dissemination and preservation http://www.consilium.europa.eu/ueDocs/cms_ Data/docs/pressData/en/intm/97236.pdf

URL33 Minerva eEurope Cultural Website Quality Principles http://www.minervaeurope.org/publications/ten qualityprinciples.htm and G. EKSTRÖM (1998): Global CMT analysis of moderate earthquakes Mw> 4.5 using intermediate period surface waves, Bull. Seismol. Soc. Am., 88, 1003-1013. 


\section{REFERENCES}

Amato, A. (2007): Developments of seismic monitoring in Italy from 1997 to 2007 , in The Colfiorito earthquake 1997-2007: ten years on. Extended abstracts. 810/10/2007, Rome, Italy, edited by: BARBA et al., 2007, http://hdl.handle.net/2122/2533.

Archuleta, R.J., J. Steidl and M. Squibb (2006): The COSMOS Virtual Data Center: A Web Portal for Strong Motion Data Dissemination, Seismological Research Letters, 77, 651-658.

Bohonus, B. (2001): Virtual Tour of Seattle Earthquake, Internet: www.vrseattle.com/pages/browse.php?cat_id=800

Bossu, R., V. Douet, S. Godet, G. Mazet-Roux and S. RIVES (2007): On the use of Internet to rapidly collect earthquake impact information, CSEM-EMSC Newsletter, 22, 31-34. Internet: http://www.emsccsem.org/Doc/EMSC_Newsletter_22.pdf

Borriello, G., F. Giudicepietro, G. Scarpato, L. D'AuRIA, M. OrAZI, P. RicCIOLINO and F. SANSIVERO (2006): Statistiche Web del sito dell'Osservatorio Vesuviano INGV. Rapporto Tecnico INGV-OV Open File Report N. 3 2006, Internet: http://www.ov.ingv.it/italiano/pubblicazioni/openfile/ofr_03_06.htm

CAJKA, M.G. and S. HALCHUK (1998): Collecting Intensity Data via the Internet: The Cap-Rouge, Québec Earthquake, Seismological Research Letters, 69, 585-587.

CAMAssi R. (2007): Macroseismic survey of the 1997-1998 Umbria-Marche earthquakes: from practice to practice in: The Colfiorito earthquake 1997-2007: ten years on. Extended abstracts. 8-10/10/2007, Rome, Italy, edited by: BARBA et al., 2007, http://hdl.handle.net/2122/2533.

DANNA, M.P. (1998): La terra sul monitor, Virtual. Il Mensile dell'Era Digitale, 52, 62-67.

De Rubeis, V., Tosi, P. and P. Sbarra (2007): Campi macrosismici di terremoti rilevanti realizzati elaborando i dati provenienti dal questionario macrosismico on line. Internet: http://terremoto.rm.ingv.it

DoumAX, F. and S. VINCI (2006): KHARITA - Portale CNT per la Cartografia Digitale. Internet: http://kharita.rm. ingv.it

EUDES, Y. and S. LUBRANO (1997): www.nettuno.it/eventi/terremoto. Deux sismologues proposent une visite de villages italiens touchés par les tremblements de terre, $L e$ Monde, October 22, 33.

Gasperini, P., F. Bernardini, G. Valensise and E. Boschi (1999): Defining seismogenic sources from historical earthquake felt reports, Bull. Seism. Soc. Am., 89, 94110.

Kradolfer, U. and S. Heimers (2003): NINTRAS - detecting earthquakes without seismic data. Internet: http://www.seismo.ethz.ch/nintras/

Jones, A., A. Michael, B. Simpson, S. Jacob and D. OpPENHEIMER (2000): Rapid Distribution of Earthquake Information for Everybody, Seismological Research Letters, 71, 355-358.

LE DREN, R. (1998): The EMSC on the Web, CSEM/EMSC Newsletter, 12, 2-3. Internet: http://www.emsccsem.org/docs/data/newsletters/newsletter_12.pdf

Malone, S. (1995a): Seismology and the information superhighway, Seismological Research Letters, 66, 28-30.

Malone, S. (1995b): More on Seismology and the infor- mation super-highway, Seismological Research Letters, 66, 35-37.

Malone, S. (1996): «Near» real-time Seismology, Seismological Research Letters, 67, 52-54.

Mazet-Roux, G., R. Bossu, E. CArreno and J. Guilbert (2008): European-Mediterranean Seismological Center Report on 2007 real time activities. Internet http://www.emsc-csem.org

MazzA, S., et al. (2006): Mednet - Mediterranean Very Broadband Seismographic Network. Internet: http://mednet.rm.ingv.it

MiNERVA WORKING GROUP 5 (2003): Handbook for quality in cultural Web sites: improving quality for citizens Version 1.2 - Draft (November 2003) edited by 'Minerva Working Group 5' Identification of user needs, contents and quality criteria for cultural Web applications Internet: http://www.minervaeurope.org/ publications/qualitycriteria1_2draft/table.htm

Mucciarelli, M., R. CAMASSI and M.R. Gallipoli (2002): Collection of Macroseismic Data in a Digital Age: Lessons from the 1999 Kocaeli, Turkey Earthquake, Seismological Research Letters, 73, 325-331.

Padula, M. and G. Rubbia RinAldi (1999): Mission-Critical Web Applications: A Seismological Case, Interactions, 4, 53-6, Internet: http://doi.acm.org/10.1145/ 306412.306435

Rubbia, G. (1998): Il web del Gruppo Nazionale per la Difesa dai Terremoti - Un'analisi speditiva per la consultazione delle sezioni istituzionale, convegni e progetti e della sezione dedicata ai terremoti umbro marchigiani del settembre/ottobre 1997 nel periodo aprile 1997-aprile 1998. Rapporto Interno GNDT, Milano, pp. 18.

Rubbia, G. (2004): L'utilizzo del sito web per la nuova mappa di pericolosità sismica: considerazioni a un anno dall'apertura. Rapporto Tecnico INGV-MI, (Milano, ottobre 2004), pp. 18.

RubBia RinALDI, G. (2000): Online Information Services for Historical Seismology, in: CASTELl, V. (Editor), Papers and memoranda from the First Workshop of the ESC Working Group «Historical Seismology», Macerata (Italy), 1-5 September 1999, 72-76.

Usa Today (1997): Usa Today Hot Sites, Online Tremors. Our guide to hot sites: For Monday, Oct. 27, 1997.

UsGs (2005): The December 26, 2004 Indian Ocean Tsunami: Initial Findings on Tsunami San Deposits, Damage, and Inundation in Sri Lanka. Internet: http://walrus.wr.usgs.gov/tsunami/srilanka05/damage.html

VAN ECK, T. (1997): ORFEUS Seismological Software Library, Seismological Research Letters, 68, 952-953.

Van Eck, T., A. Spinuso, V. Douet and R. Bossu (2007): «Portal concept and strategy Plan», Activity document NA7- Portal for integrated data dissemination, Sixth Framework Programme EC project NERIES NETwork of Research Infrastructures for European Seismology EC project number 026130. Internet: http://neries.knmi.nl/

WaLD, D. (1997): Surfing the Internet for Strong-motion Data, Seismological Research Letters, 68, 766-769.

Wald, D.J., V. Quitoriano, L.A. Dengler and J.W. DEWEY (1999): Utilization of the Internet for Rapid Community Intensity Maps, Seismological Research Letters, 70, 680-697. 